\title{
Serum angiotensin converting enzyme, ceruloplasmin, and lactic dehydrogenase in anthracosilicosis and anthracosilicotuberculosis
}

\author{
S ZHICHENG, Y ZHIMING, A LATA, H YUHUA
}

From the Department of Occupational Medicine, Third Hospital, Beijing Medical University, Beijing, China

We have determined the activities of serum angiotensin converting enzyme (SACE), ceruloplasmin (SCP), and lactic dehydrogenase (SLDH) in anthracosilicosis and anthracosilicotuberculosis in order to see if any biochemical changes take place and to find laboratory indices for the early diagnosis and evaluation of the treatment in patients with anthracosilicosis and anthracosilicotuberculosis.

\section{Subjects and methods}

\section{SUBJECTS}

On the basis of changes seen in the chest $x$ ray films 95 male anthracosilicotic patients were recruited with the study. They included 24 suspected cases, 25 cases in category 1,24 in category 2 , and 22 in category 3 . In addition, the study included 20 cases of anthracosilicotuberculosis. The ages of the subjects ranged from 32 to 73 (mean $48 \cdot 7 \pm 9 \cdot 1$ ) with a working life from six to 34 years (mean 12.8 \pm 4.8 ) and all had been exposed to both silica and coal dust in coal mines. Twenty four male workers with mixed dust exposure with an age range of 30-63 (mean $48 \cdot 1 \pm$ $5 \cdot 3$ ) and 26 healthy men with no dust exposure and an age range of $26-55$ (mean $44.3 \pm 6 \cdot 7$ ) served as controls.

\section{METHODS}

SACE was analysed using ultraviolet spectrophotometry with hippurylglycine glycyl as substrate as described by Lieberman et al. ${ }^{1}$ SCP was assayed using the photoelectrometric method of Bauer et $\mathrm{al}^{2}$ and SLDH by the colorimetric method of Frankel et al. ${ }^{3}$

The mean and standard deviations were calculated for each variable; comparison between the different groups was carried out using Student's $t$ test fog unpaired data.

\section{Results}

The results are shown in tables 1 and 2 .

Table $1 S A C E, S C P$, and $S L D H$ values $(M \pm S D)$

\begin{tabular}{|c|c|c|c|c|}
\hline Group & No of cases & $S A C E(u / m l)$ & $S C P(u / d l)$ & $S L D H(u / d l)$ \\
\hline Normal & 26 & $\begin{array}{l}33 \cdot 44 \pm 12 \cdot 84 \\
(26 \cdot 10-56 \cdot 74)\end{array}$ & $\begin{array}{l}299 \cdot 96 \pm 57 \cdot 41 \\
(215-380)\end{array}$ & $\begin{array}{l}314 \cdot 35 \pm 78 \cdot 26 \\
(120-402)\end{array}$ \\
\hline Exposed & 24 & $\begin{array}{l}43 \cdot 29 \pm 16 \cdot 65 \\
(23 \cdot 13-93 \cdot 71)\end{array}$ & $\begin{array}{l}308 \cdot 50 \pm 63 \cdot 01 \\
(190-465)\end{array}$ & $\begin{array}{l}313 \cdot 13 \pm 100 \cdot 47 \\
(148-509)\end{array}$ \\
\hline Suspected & 24 & $\begin{array}{l}44 \cdot 22 \pm 17.94 \\
(14.07-78 \cdot 29)\end{array}$ & $\begin{array}{l}357 \cdot 75 \pm 80 \cdot 17 \\
(210-505)\end{array}$ & $\begin{array}{l}310 \cdot 38 \pm 94 \cdot 52 \\
(191-578)\end{array}$ \\
\hline Category 1 & 25 & $\begin{array}{l}53.14 \pm 18.65 \\
(27.20-89.32)\end{array}$ & $\begin{array}{l}439.00 \pm 103.65 \\
(245-590)\end{array}$ & $\begin{array}{l}347 \cdot 57 \pm 81 \cdot 59 \\
(202-597)\end{array}$ \\
\hline Category 2 & 24 & $\begin{array}{l}53.53 \pm 14.62 \\
(27.85-89.54)\end{array}$ & $\begin{array}{l}595 \cdot 46 \pm 115 \cdot 13 \\
(400-870)\end{array}$ & $\begin{array}{l}342 \cdot 88 \pm 77 \cdot 00 \\
(123-477)\end{array}$ \\
\hline Category 3 & 22 & $\begin{array}{l}63 \cdot 32 \pm 23 \cdot 98 \\
(20 \cdot 13-144 \cdot 26)\end{array}$ & $\begin{array}{l}645 \cdot 68 \pm 126 \cdot 51 \\
(437-960)\end{array}$ & $\begin{array}{l}373 \cdot 86 \pm 65 \cdot 18 \\
(142-558)\end{array}$ \\
\hline Anthracosilicotuberculosis & 20 & $\begin{array}{l}48 \cdot 39 \pm 17 \cdot 00 \\
(18 \cdot 21-87 \cdot 18)\end{array}$ & $\begin{array}{l}583 \cdot 55 \pm 118.90 \\
(330-1000)\end{array}$ & $\begin{array}{l}362 \cdot 30 \pm 138 \cdot 80 \\
(176-736)\end{array}$ \\
\hline
\end{tabular}


Table 2 Statistical significance of differences among the groups ( $p$ value)

\begin{tabular}{|c|c|c|c|c|c|c|}
\hline & $A v s B$ & $A v s C$ & $A v s D$ & $A v s E$ & $A v s F$ & $A v s G$ \\
\hline \multirow[t]{2}{*}{$\begin{array}{l}\text { SACE } \\
\text { SCP } \\
\text { SLDH }\end{array}$} & $\begin{array}{l}>0.05 \\
>0.05 \\
\text { NS }\end{array}$ & $\begin{array}{l}>0.05 \\
>0.05 \\
\text { NS }\end{array}$ & $\begin{array}{l}<0.01 \\
<0.01 \\
\text { NS }\end{array}$ & $\begin{array}{l}<0.01 \\
<0.01 \\
\mathrm{NS}\end{array}$ & $\begin{array}{l}<0.01 \\
<0.01 \\
\text { NS }\end{array}$ & $\begin{array}{l}<0.05 \\
<0.01 \\
\text { NS }\end{array}$ \\
\hline & $B v s C$ & $B v s D$ & BvsE & BvsF & $B v s G$ & \\
\hline \multirow[t]{2}{*}{$\begin{array}{l}\text { SACE } \\
\text { SCP } \\
\text { SLDH }\end{array}$} & $\begin{array}{l}>0.05 \\
>0.05 \\
\text { NS }\end{array}$ & $\begin{array}{l}<0.05 \\
<0.05 \\
\text { NS }\end{array}$ & $\begin{array}{l}<0.05 \\
<0.01 \\
\mathrm{NS}\end{array}$ & $\begin{array}{l}<0.01 \\
<0.01 \\
\text { NS }\end{array}$ & $\begin{array}{l}>0.05 \\
<0.01 \\
\mathrm{NS}\end{array}$ & \\
\hline & CvsD & CvsE & CvsF & $C v s G$ & & \\
\hline \multirow[t]{2}{*}{$\begin{array}{l}\text { SACE } \\
\text { SCP } \\
\text { SLDH }\end{array}$} & $\begin{array}{l}>0.05 \\
>0.05 \\
\text { NS }\end{array}$ & $\begin{array}{l}>0.05 \\
<0.05 \\
\text { NS }\end{array}$ & $\begin{array}{l}<0.01 \\
<0.01 \\
\text { NS }\end{array}$ & $\begin{array}{l}>0.05 \\
<0.01 \\
\text { NS }\end{array}$ & & \\
\hline & DvsE & $D v s F$ & $D v s G$ & EvsF & $E v s G$ & FvsG \\
\hline $\begin{array}{l}\text { SACE } \\
\text { SCP } \\
\text { SLDH }\end{array}$ & $\begin{array}{l}>0.05 \\
<0.05 \\
\text { NS }\end{array}$ & $\begin{array}{l}<0.05 \\
<0.05 \\
\text { NS }\end{array}$ & $\begin{array}{l}>0.05 \\
<0.05 \\
\text { NS }\end{array}$ & $\begin{array}{l}>0.05 \\
>0.05 \\
\text { NS }\end{array}$ & $\begin{array}{l}>0.05 \\
>0.05 \\
\text { NS }\end{array}$ & $\begin{array}{l}>0.05 \\
>0.05 \\
\text { NS }\end{array}$ \\
\hline
\end{tabular}

\section{Discussion}

Angiotensin converting enzyme (ACE) or peptidylpeptide hydrolase exists in part on the endothelial surface of the pulmonary capillaries. The human alveolar macrophages contain and may secrete ACE. Factors that are harmful to endotheliocytes and macrophages can release ACE. The SACE level is greatly raised in active sarcoidosis and, recently, raised SACE levels have been reported in silicosis and asbestosis. ${ }^{45}$ The results of our study confirm that levels of SACE and SCP in anthracosilicosis and anthracosilicotuberculosis are higher than in controls and that the rise in SACE and SCP levels is associated with the progression of anthracosilicosis. In addition, the rise in SACE level closely paralleled the rise in SCP levels. We consider that the rise in SACE and SCP levels is a signal both of the continuing harm done to the pulmonary macrophages and of the progression of pulmonary fibrosis. Therefore, SACE and SCP may be used clinically as an index to show the progression of pulmonary fibrosis, as well as to evalute the effects of treatment.

Since the levels of SACE and SCP are also increased in patients with anthracosilicotuberculosis, they cannot be used to differentiate anthracosilicosis from anthracosilicotuberculosis.

\section{References}

1 Lieberman J. Elevation of serum angiotensin-converting enzyme (ACE) level in sarcoidosis. Am J Med 1975;59:365-72.

2 Bauer JD, Ackermann PG, Gelson T. Ceruloplasmin. In: Clinical laboratory methods. 8th ed. Saint Louis: CV Mosby Company, 1974:477-8.

3 Frankel S, Reitman S, Sonnenwirth AC. Lactic acid dehydrogenase (LDH). In: Gradwohl's clinical laboratory methods and diagnosis. 7th ed. Vol 1. Saint Louis: CV Mosby Company, 1970:129.

4 Gronhagen-Riska C, Kurppak, Fyhrquist F, Selroos O. Angiotensin-converting enzyme and lysozyme in silicosis and asbestosis. Scand J Respir Dis 1978;59:228-31.

5 Bucca C, Veglio F, Rolla G, et al. Serum angiotensin converting enzyme (ACE) in silicosis. Eur J Respir Dis 1984;65:477-80. 